\title{
Giant cerebellopontine angle schwannoma in a child
}

\author{
Brandon C Gabel, ${ }^{1}$ Robert O Newbury, ${ }^{2}$ Michael L Levy, ${ }^{1}$ John Ross Crawford ${ }^{3}$
}

'Department of Neurosurgery, University of California San Diego, San Diego, California, USA

${ }^{2}$ Department of Pathology, University of California San Diego, San Diego, California, USA

${ }^{3}$ Department of Neurosciences and Pediatrics, University of California San Diego, San Diego, California, USA

\section{Correspondence to} Dr John Ross Crawford, jrcrawford@ucsd.edu
To cite: Gabel BC Newbury RO, Levy ML, et al. BMJ Case Rep Published online: [please include Day Month Year] doi:10.1136/ bcr-2013-201253

\section{DESCRIPTION}

A 6-year-old boy presented with a 6-month history of worsening gait, abnormal eye movements and head tilt. Neurological examination revealed papilloedema, gaze-evoked nystagmus, decreased rightsided hearing, decreased sensation in the right V1 trigeminal nerve distribution, bilateral dysmetria and ataxic gait. MRI demonstrated a large contrast-enhancing, right-sided cerebellopontine angle tumour with mass effect on the fourth ventricle and invasion of the cavernous sinus (figure 1). T2-weighted MRI sequences showed enlargement of optic nerve sheaths and protrusion of optic nerve heads consistent with increased intracranial pressure (figure 1C). Subtotal resection of the mass consisted of a spindle cell neoplasm with palisading nuclei forming Verocay bodies, and both Antoni A and B patterns, consistent with a diagnosis of schwannomas (figure 2). Postoperatively he required prolonged rehabilitation due to complications from surgery including right-sided cranial neuropathy and left hemiparesis that resolved over several weeks. Owing to residual disease in the brainstem and cavernous sinus, the patient underwent conformal intensity modulated radiation therapy and remained stable for almost 3 years postdiagnosis. Genetic testing for neurofibromatosis types 1 and 2 was negative and the child had no neurocutaneous findings.

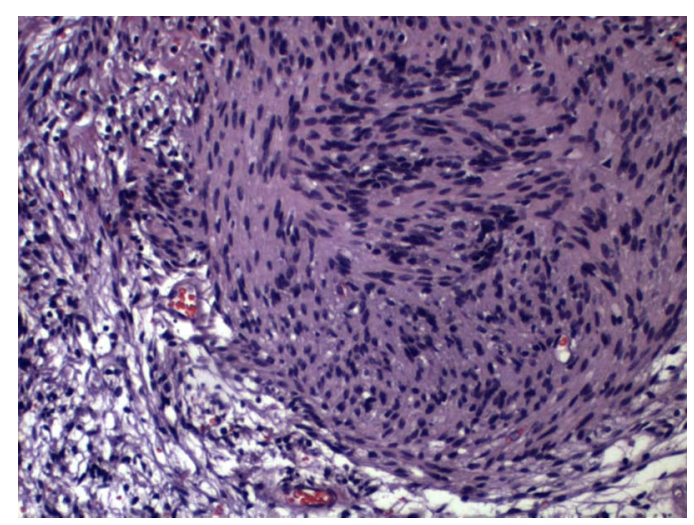

Figure 2 Histopathological features of cerebellopontine angle schwannoma. Schwannoma with compact Antoni A bland spindle Schwann cells on the right side with loose Antoni $B$ region of the left. Focal nuclear palisading with Verocay body formation (H\&E $\times 200)$.

Schwannomas of the cerebellopontine angle are uncommon in the absence of acoustic nerve involvement. There have been a limited number of case reports of spontaneous intracranial schwannomas in children. ${ }^{12}$ Up to $40 \%$ of children with cerebellopontine angle tumours may be negative for neurofibromatosis type $2 .^{2}$ Our case expands the differential diagnosis of cerebellopontine angle

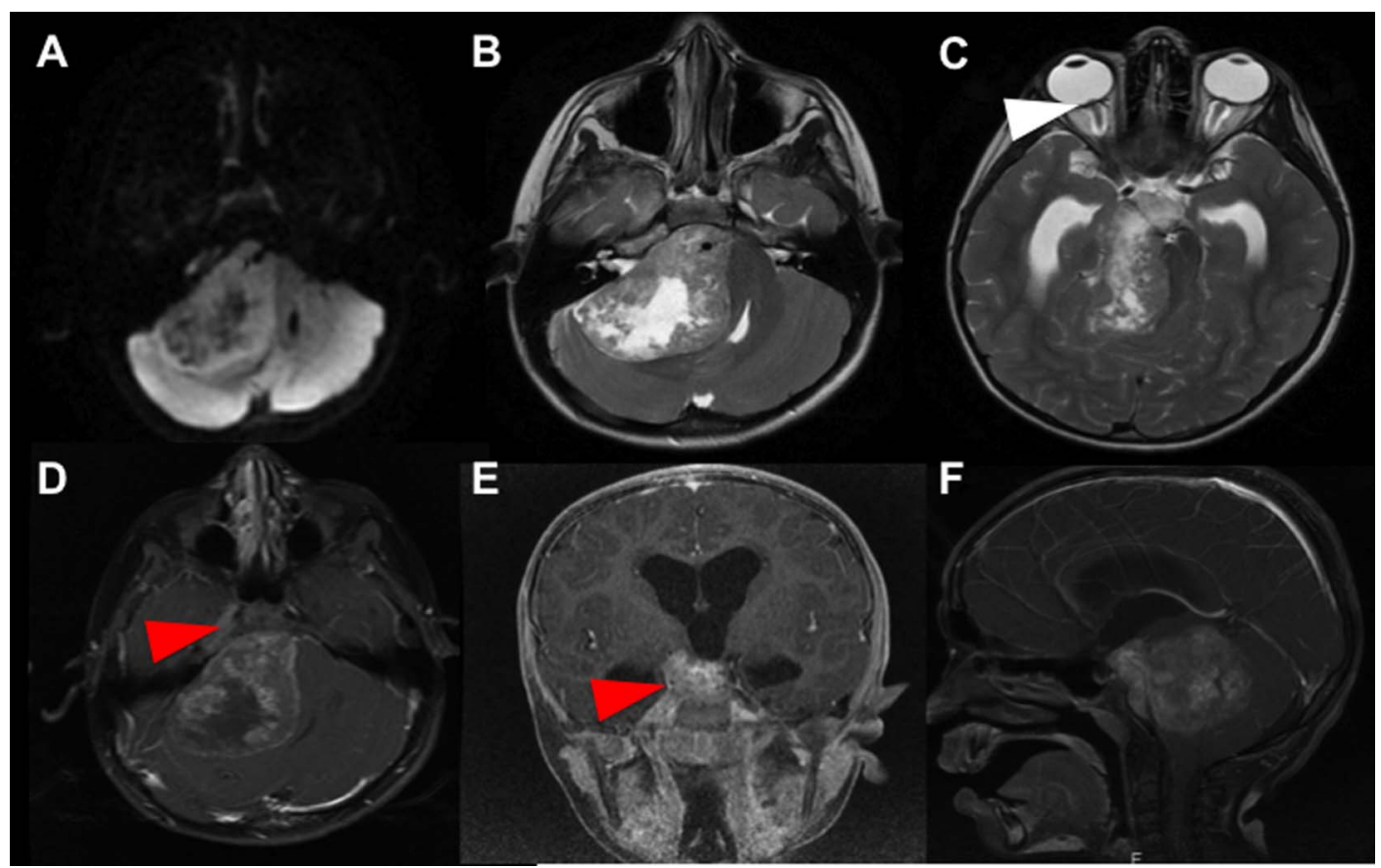

Figure 1 MRI features of cerebellopontine angle schwannoma. Diffusion-weighted imaging reveals a large cerebellar pontine angle neoplasm without reduced diffusivity (A) and without involvement of the internal auditory canal (B). T2-weighted MRI sequences demonstrate enlargement of optic nerve sheaths and protrusion of optic nerve heads (white arrowhead) consistent with elevated intracranial pressure (C). Postgadolinium sequences (D-F) demonstrate invasion of the right-sided cavernous sinus (red arrowheads). 
tumours of childhood to include schwannoma in the absence of neurofibromatosis.

\section{Learning points}

- Intracranial schwannoma may be associated with diverse neurological findings including cranial neuropathies due to the invasive potential.

- Schwannoma should be considered in the differential diagnosis of cerebellopontine angle tumours in children and may occur in the absence of a diagnosis of neurofibromatosis.
Contributors All authors have contributed equally to the design and writing the manuscript.

Competing interests None.

Patient consent Obtained.

Provenance and peer review Not commissioned; externally peer reviewed.

\section{REFERENCES}

1 Santarius T, Dakoji S, Afshari FT, et al. Isolated hypoglossal schwannoma in a 9 year old child. J Neurosurg Pediatr 2012;10:130-3.

2 Holman MA, Schmitt WR, Carlson ML, et al. Pediatric cerebellopontine angle and internal auditory canal tumors. I Neurosurg Pediatr. Published Online First: 2 Aug 2013. doi:10.3171/2013.6.PEDS1383.

Copyright 2013 BMJ Publishing Group. All rights reserved. For permission to reuse any of this content visit http://group.bmj.com/group/rights-licensing/permissions.

BMJ Case Report Fellows may re-use this article for personal use and teaching without any further permission.

Become a Fellow of BMJ Case Reports today and you can:

- Submit as many cases as you like

- Enjoy fast sympathetic peer review and rapid publication of accepted articles

- Access all the published articles

- Re-use any of the published material for personal use and teaching without further permission

For information on Institutional Fellowships contact consortiasales@bmjgroup.com

Visit casereports.bmj.com for more articles like this and to become a Fellow 